\title{
DEVELOPMENT OF PERSONALITY COMPETENCE OF PRESERVICE TEACHER AT DISRUPTION ERA
}

\author{
Siti Zumrotul Maulida, Ifah Silfianah, Ainun Nikmati Laily
}

IAIN Tulungagung

zumrotul.sm@gmail.com

\section{Article History}

accepted 09/07/2018

approved 01/08/2018

published 17/09/2018

\section{Keywords}

Disruption Era,

Personality, Preservice

Teacher

\begin{abstract}
The disruption era is a challenge for the education sector because education is one of the areas that can support the quality of Indonesian human resources according to Kemenristekdikti priorities. This article aims to explore the development of personality competencies of preservice teachers in facing the challenges of disruption era. The function of teachers in the disruption era is different from that of teachers in the previous era, which is shifting to the function of cultivating ethical values, character, wisdom, experience, and social empathy because the function is impossible to do by machine. Thus, the challenge of educational institutions is to form the competence of preservice teacher personality which will buildsuitable exemplary based on expectation of teacher's role revolution in disruption era. There are four things that can be done in developing the personality competence of preservice teachers, some of them are: 1). religious matriculation programs, 2). application of student code of conduct, 3) Real Work Experience (KKN) program, and 4). integration of religious values in lectures.
\end{abstract}

Social, Humanities, and Education Studies (SHEs): Conference Series https://jurnal.uns.ac.id/shes
p-ISSN 2620-9284

e-ISSN 2620-9292 


\section{PENDAHULUAN}

Saat ini dunia dihadapkan pada era disrupsi tak terkecuali Indonesia. Dalam Kamus Besar Bahasa Indonesia (2007) era disrupsi, diartikan hal tercabut dari akarnya. Definisi tersebut dimaknai terjadinya perubahan yang mendasar pada berbagai bidang, salah satunya dalam bidang pendidikan. Digitalisasi di bebagai bidang memudahkan siswa menggali pengetahuan; belajar ilmu pengetahuan dengan mudah tanpa melibatkan guru ataupun orangtua. Hal ini sangat membantu pemahaman siswa dalam bidang kognitif dan keterampilannya. Namun, dalam bidang afektif siswa, peran guru tidak dapat digantikan dengan kecanggihan teknologi apapun. Kepribadian guru yang baik sangat dibutuhkan oleh siswa sebagai teladan untuk membentuk karakternya bukan sebaliknya. Sangat menyedihkan ketika terdapat kasus-kasus yang menunjukkan guru melakukan tindakan yang tidak terpuji (kekerasan fisik, kekerasan psikologis, dan kekerasan seksual) seperti yang diberitakan pada berbagai media. Kristoto, P., Zakso, A., \& Rivale, W. (2015) dalam hasil penelitiannya menyatakan bahwa kompetensi kepribadian guru adalah baik, namun memiliki kekurangan dalam penerapannya dalam indikator mantap dan stabil, dewasa dan arif.

Informasi apa pun dan dari belahan dunia manapun dapat dengan mudah diakses siswa karena kecanggihan teknologi dan informasi. Dasarnya, kecanggihan teknologi dan informasi sangat bermanfaat untuk menambah wawasan dan mengembangkan berbagai ilmu pengetahuan namun dampak negatif pun tidak dapat dihindari. Diantaranya, siswa dapat mengakses video porno dengan mudah; melihat berbagai tindak kekerasan; dan gaya hidup konsumtif dan hedonis. Akibatnya, banyak kejadian siswa melakukan tindak kekerasan dengan teman atau guru, pencurian, bahkan sampai tindakan pembunuhan. Selain itu, kecanggihan telepon pintar dapat juga menyebabkan siswa kecanduan telepon pintar; berkurangnya kuantitas dan kualitas komunikasi antara orang tua dan anak; tidak mengindahkan etika dan kesopanan ; serta berbagai kasus asusila.

Dampak negatif dari kecanggihan teknologi dan informasi tersebut mengindikasikan adanya degradasi moral bagi bangsa Indonesia. Hal ini memerlukan perhatian dan penanganan yang serius dari semua elemen masyaraka dan pemerintah. Kemajuan dan keberhasilan sebuah negara dapat dilihat dai keberhasilannya dalam dunia pendidikan. Salah satu komponen penting dalam pendidikan adalah guru. Peranannya sebagai pendidik sangat diperlukan. Karena keberadaannya dalam dunia pendidikan terutama di Indonesia sangat dibutuhkan. Pemerintah secara khusus mengatur peranannya dalam Undang-Undang Nomor 14 Tahun 2005 tentang Guru dan Dosen pada Pasal 10. Undang-undang tersebut menyatakan bahwa guru harus memiliki empat kompetensi, salah satunya adalah kompetensi kepribadian. Kompetensi kepribadian guru menurut Peraturan Menteri Pendidikan Nasional Republik Indonesia Nomor 16 Tahun 2007 tentang Standar Kualifikasi Akademik dan Kompetensi Guru diantaranya (1) bertindak sesuai dengan norma agama, hukum, social, dan kebudayaan nasional Indonesia; (2) menampilkan diri sebagai pribadi yang jujur, berakhlak mulia, dan teladan bagi peserta didik dan masyarakat; (3) menampilkan diri sebagai pribadi yang mantap, stabil, dewsa, arif, dan berwibawa; (4) menunjukkan etos kerja, tanggung jawab yang tinggi, rasa bangga menjadi guru, dan rasa percaya diri; dan (5) menjunjung tinggi kode etik profesi guru.

Berbagai penelitian tentang kompetensi kepribadian guru telah dilakukan oleh beberapa peneliti, diantaranya penelitian yang dilakukan oleh Kristoto, P., Zakso, A., \& Rivale, W. (2015) menunjukkan bahwa terdapat pengaruh yang positif antara kompetesi keribadian guru terhadap hasil belajar siswa.Sementara itu, hasil penelitian Aprilliyanti, Eka and Wahyu, Wahyu and Adawiah, Rabiatul (2013) menunjukkan bahwa terdapat hubungan antara kompetensi kepribadian guru terhadap sikap demokratis siswa. Hal tersebut dibuktikan dengan hasil wawancara kepada para siswa. Pendapat 
siswa yang diwawancarai menyatakan bahwa siswa akan bersemagat belajar, kritis dalam pembelajaran, berani menyampaikan pendapat tanpa rasa takut jika guru memiliki kepribadian yang baik (ramah, kreatif, inovatif, dan lain-lain). Selanjutnya, Kheruniah, A.E. (2013) dalam penelitiannya juga menyatakan bahwa kompetensi kepribadian guru memberikan pengaruh yang positif terhadap motivasi dan disiplin belajar siswa. Berdasarkan berbagai penelitian tersebut, menunjukkan bahwa kompetensi kepribadian guru berkontribusi dalam pembentukan karakter siswa. Adapun penulisan artikel ini bertujuan untuk memberikan gambaran pengembangan kompetensi kepribadian calon guru untuk menghadapi tantangan era disrupsi terutama dalam bidang pendidikan.

\section{HASIL DAN PEMBAHASAN}

Kegiatan perkuliahan merupakan hal yang wajib diikuti oleh mahasiswa sebagai calon guru dan mahasiswa pada umumnya. Perkuliahan tempat mengembangkan kemampuannya baik kemampuan kognitif maupun afektif. Pengembangan kemampuan kognitif diperuntukkan bagi wawasan pengetahuannya. Adapun pengembangan kemampuan afektif untuk membentuk kepribadiannya. Agar para mahasiswa memiliki keprbadian yang baik, seyogyanya kampus menyediakan fasilitas dan layanan berbagai program untuk menunjang terbentuknya kepribadian yang baik tersebut. Terdapat beberapa program yang diharapkan mampu membentuk kepribadian baik mahasiswa (calon guru). Berikut ini adalah beberapa program yang dilaksanakan oleh Institut Agama Islam (IAIN) Tulungagung umumnya dan Fakultas Tarbiyah dan Ilmu Keguruan (FTIK) khususnya dalam rangka membentuk kompetensi kepribadian yang baik bagi para calon guru. Adapun program-program tersebut akan dipaparkan berikut ini.

\section{Program Matrikulasi Kuliah Agama}

Perguruan tinggi sebagai pencetak calon guru (pendidik) berkontribusi dalam membekali para mahasiswanya untuk menjadi guru yang berkompetensi. Apalagi akan dihadapkan pada era disrupsi. Institut Agama Islam Negeri (IAIN) Tulungagung merupakan salah satu perguruan tinggi pencetak para calon guru melalui Fakultas Tarbiyah dan IImu Keguruan (FTIK). Dalam rangka mempersiapkan para calon guru, berbagai program telah dilaksanakan oleh IAIN Tulungagung. Salah satunya mempersiapkan kompetensi kepribadian bagi para calon guru.

Sesuai dengan PP Nomor 19 tahun 2005 tentang Standar Nasional Pendidikan Bab VI Pasal 28 ayat 3 menyatakan bahwa seorang guru minimal memiliki empat kompetensi, diantaranya kompetensi kepribadian. Selanjutnya dijelaskan bahwa kompetensi kepribadian adalah seperangkat kemampuan karakteristik personal yang mencerminkan realitas sikap dan perilaku guru dalam melaksanakan tugas-tugasnya dalam kehidupan sehari-hari. Kompetensi kepribadian ini melahirkan konsekuensi ciriciri guru, diantaranya sabar, tenang, tanggung jawab, demokratis, ikhlas, cerdas, menghormati orang lain, dan lain-lain (Ali: 2016). Lebih lanjut Karwono dan Heni (2017) menjelaskan bahwa "Kompetensi kepribadian adalah kemampuan kepribadian guru dan dosen yang mantap, berakhlak mulia, berwibawa dan menjadi teladan bagi peserta didiknya".

Guna memenuhi ciri-ciri guru yang berkompetensi kepribadian perlu dilakukan tindakan nyata oleh lembaga atau institusi pencetak calon guru. Sesuai dengan tuntutan Tri Dharma Perguruan Tinggi, setiap perguruan tinggi harus memenuhi tiga fungsi, yaitu sebagai sarana pendidikan, penelitian, dan pengabdian. Untuk memenuhi fungsi pendidikan, IAIN Tulungagung mencanangkan sebuah program pendidikan untuk mewujudkan kompetensi kepribadian guru di luar kurikulum perkuliahan yang 
sudah dijadwalkan. Program tersebut dinamai Matrikulasi Pendidikan Agama. Program ini merupakan prakarsa Rektor IAIN Tulungagung yang direalisasikan mulai tahun akademik 2017-2018.

Tujuan pelaksanaan program Matrikulasi Pendidikan Agama (PMA) ini untuk membekali seluruh mahasiswa IAIN Tulungagung umunya dan para calon guru khususnya. Bekal agar mahasiswa memiliki kompetensi kepribadian yang andal dan mampu menghadapi dunia pendidikan di Era Disrupsi. Program ini dikelola oleh Ma'had al-Jamia'ah IAIN Tulungagung. Matrikulasi berlangsung 2 semester bagi mahasiswa baru pada semester 1 dan 2. Pada tahun akademik 2017-2018 sebanyak 4000 mahaisiwa baru mengikuti program ini. Waktu perkuliahan jam $07.00-08.30$ WIB. Semua lokal kuliah pada jam tersebut digunakan untuk program matrikulasi ini. Mahasiswa baru yang mengikuti program ini disebut "mahasantri". Kuliah yang berlansung 2 semester ini di akhir pendidikan diadakan evaluasi serta haflah akhiris sanah 'akhir tahun ajaran' semacam wisuda. Mengingat kebutuhan pengajar dalam program ini sangat banyak dan kemampuan dosen di IAIN Tulungagung yang berkompetensi dalam bidang ini terbatas, kekurangan pengajar ditambah dari lembaga yang lebih kompeten dari luar kampus. Adapun lembaga yang ikut serta dalam mengajar di program ini dari Lembaga Ma'arif NU Tulungagung, Jamiatul Quro' wal Khufad Kabupaten Tulungagung, serta dari pondok pesantren.

Matrikulasi Pendidikan Agama ini memiliki 3 mata ajar, yaitu Baca Tulis al Quran (BTQ), Madrasah Diniyah (Madin), dan Program Tilawah. Tujuan utama program Matrikulasi Pendidikan Agama ini adalah:

(1) membekali mahasiswa agar tidak terpengaruh akidah radikal;

(2) mencetak lulusan yang pandai dalam ilmu dunia dan ilmu agama (tafaqquh $\mathrm{fi}$ ulum al dunya, tafaqquh fi ulum al din);

(3) membentuk karakter lulusan yang berpandangan luas, pengayom masyarakat, bijak, dan ramah.

Adapun penjenjangan pengajaran Matrikulasi Pendidikan Agama kepada mahasiswa baru ini didasarkan pada kemampuan baca tulis al Quran yang dapat dilihat pada tabel di bawah ini.

Tabel 1.Penjenjangan Matrikulasi Pendidikan Agama

\begin{tabular}{|l|l|l|}
\hline \multicolumn{1}{|c|}{ Nama Kelas } & \multicolumn{1}{c|}{$\begin{array}{c}\text { Kemampuan Awal } \\
\text { Mahasiswa }\end{array}$} & \multicolumn{1}{c|}{ Tujuan Program } \\
\hline Baca Tulis al Quran & Buta huruf al Quran & $\begin{array}{l}\text { Mampu membaca dan } \\
\text { menulis al Quran }\end{array}$ \\
\hline $\begin{array}{l}\text { Madrasah Diniyah } \\
\text { (Madin) }\end{array}$ & $\begin{array}{l}\text { Lancar baca tulis al } \\
\text { Quran dan tartil }\end{array}$ & $\begin{array}{l}\text { Pendalaman materi } \\
\text { secara teori dan praktik }\end{array}$ \\
\hline Tilawah & $\begin{array}{l}\text { Lancar baca tulis al } \\
\text { Quran, tartil dan } \\
\text { bersuara bagus }\end{array}$ & $\begin{array}{l}\text { Menghafal al Quran } \\
\text { dan tilawatil Quran }\end{array}$ \\
\hline
\end{tabular}

Baca tulis al Quran merupakan perwujudan upaya awal membudayakan literasi karena sebelum memulai aktivitas perkuliahan didahului dengan budaya membaca al Quran. Dengan membaca al Quran pada akhirnya mahasiswa diharapkan mampu memahami isi kandungan al Quran dan mengimplementasikannya dalam kehidupan sehari-hari terutama dalam bidang ilmu pengetahuan. Dengan membaca dan memahami al Quran diharapkan mahasiswa akan mampu menguak dan memperdalam ilmu pengetahuan yang bersumber dari al Quran. Sebagaimana dipaparkan oleh Thayyarah (2013) "Meskipun ilmu pengetahuan kini berkembang sedemikian pesat, tak satu pun teori ilmiah tersebut yang bertentangan dengan al Quran. Adapun teori-teori yang belum terbukti secara ilmiah maka hal itu tak perlu diperbandingkan dengan 
kalam Tuhan. Mungkin saja kemajuan ilmu pengetahuan dan teknologi pada masa depan akan mengungkap kebenaran dan kekeliruannya". Selain itu, dengan pembiasaan kegiatan matrikulasi agama ini akan memperkuat akhlak, kepribadian, dan kedisiplinan mahasiswa. Hal ini juga diperkuat oleh penelitian Indirawati(2006) pada Fakultas Bahasa dan Seni UNY dan Fakultas Tarbiyah IAIN yang menunjukkan bahwa terdapat pengaruh kematangan bergama terhadap kecenderungan strategi coping.Strategi ini memiliki arti bahwa mahasiswa yang memiliki kematangan agama bagus akan memiliki strategi atau pilihan cara berupa respon perilaku dan responpikiran serta sikap yang digunakan dalam rangka memecahkan permasalahan yangada agar dapat beradaptasi dalam situasi menekan.

Kematanganagama inilah yang menjadi rujukan bagi mahasiswa agar mereka mudah beradaptasi dengan masalah dan menyelesaikannya sehingga menjadikannya sebagai calon guru yang dewasa arif, dan bijaksana. Hal tersebut sebagaimana disebutkan dalam Peraturan Menteri Pendidikan Nasional Republik Indonesia Nomor 16 Tahun 2007 yaitu "salah satu indikator kompetenasi kepribadianadalah menampilkan diri sebagai pribadi yang mantap, stabil, dewasa, arif, dan berwibawa". Selain itu, jika subtansi kelompok Matakuliah Pengembangan Kepribadian (MPK) yang terdapat pada Keputusan Direktur Jenderal Pendidikan Tinggi Departemen Pendidikan Nasional Republik Indonesia Nomor 43/DIKTI/Kep/2006 Tentang Rambu-RambuRambu Pelaksanaan Kelompok Matakuliah pengembangan Kepribadian di Perguruan Tinggi dikaji lebih lanjut, terdapat beberapa keilmuan yang diajarkan seperti pendidikan agama dan pendidikan kewarganegaraan. Namun, pengajaran kedua mata kuliah tersebut hanya memiliki porsi yang sedikit yakni 2 sks selama masa perkuiahan sehingga kurang berdampak dalam kematangan beragama mahasiswa. Untuk itu, PMA mengajarkan pemahaman agama kepada mahasiswa agar lebih mendalamkematangan beragamanya. Kematangan beragama akan menjadi alternatif yang mempengaruhi kepribadian mahasiswa.

\section{Kode Etik Mahasiswa}

Seperti halnya perguruan tinggi lain, kode etik mahasiswa diterapkan kepada mahasiswa IAIN Tulungagung. Kode etik mahasiswa terangkum dalam etika kampus yaitu sebagai pedoman moral dalam rangka mencapai tujuan pendidikan IAIN Tulungagung sesuai dengan visi dan misi yang diemban. Etika kampus ini meliputi etika dosen, etika pegawai, dan etika mahasiswa. Berdasarkan Buku Pedoman Penyelenggaraan Pendidikan FTIK IAIN Tulungagung (2017-2018) secara umum etika mahasiswa terdiri atas 7 etika.

Ketujuh etika mahasiswa di atas dijabarkan menjadi butir-butir kode etik mahasiswa yang disesuaikan dengan situasi dan kondisi sepanjang tidak keluar dari nilai-nilai yang ada. Kode Etik Mahasiswa (KEM) terdiri atas XI Bab dan 14 Pasal. Pada Bab II Pasal 2 dan 3 memuat maksud dan tujuan KEM. Adapun maksud KEM adalah a) menjalankan dan menjunjung tinggi nilai keislaman, berbangsa dan kenegaraan; b) menjunjung tinggi nama baik almameter IAIN di dalam kampus dan di luar kampus; c) menanamkan akhlakul karimah dalam bersikap, berbuat, berbakata, dan berbusana di kampus IAIN dan di masyarakat; dan d) memberikan dasar, arah dan pedoman perilaku selama menempuh studi di IAIN Tulungagung. Sedangkan tujuan KEM adalah a) terciptanya suasana yang kondusif bagi kelangsungan proses belajar dan pembelajaran di IAIN; b) terwujudnya mahasiswa yang berakhlakul karimah baik dalam bersikap dan berbusana.

3. Kuliah Kerja Nyata (KKN)

Program pengabdian masyarakat sebagai bentuk perwujudan Tri Dharma Perguruan Tinggi bagi mahasiswa adalah Kuliah Kerja Nyata (KKN). KKN yang dilakukan oleh mahasiswa bukan berarti mahasiswa mengajar masyarakat tentang sesuatu yang terbaik untuk mereka. Mahasiswa melakukan upaya partisipasi dalam kegiatan masyarakat sebagai sebuah proses pencarian (research) yang dilakukan 
bersama-sama untuk mencari jalan terbaik dalam menyelesaikan persoalan yang mereka hadapi. Mahasiswa melakukan tugas pendampingan terhadap apa yang dibutuhkan oleh masyarakat dalam menghadapi problem sosial di tengah-tengah mereka. Untuk itu, mahasiswa benar-benar diminta pengabdiannya kepada masyarakat. Perubahan global dan nasional menjadikan setiap perguruan tinggi mengupayakan perubahan model KKN yang ideal agar benar-benar dirasakan manfaatnya oleh masyarakat.

Dalam rangka memenuhi kebutuhan masyarakat melalui program KKN, IAIN Tulungagung mencanangkan program KKN untuk mahasiswa dalam berbagai model yaitu:

1) KKN Internasional (Thailand Selatan/Patani)

2) KKN Kebangsaan (Lampung dan Lombok)

3) KKN Tematik Revolusi Mental (Bakung, Blitar Selatan)

4) KKN Tematik Pemberdayaan Masyarakat Multisektoral Berbasis Potensi Lokal (Tulungagung dan Trenggalek)

Keempat model KKN di atas diatur dalam kerangka acuan yang memuat semua hal yang terkait dengan KKN. Tujuan umum pelaksanaan semua KKN tidak lain untuk membekali mahasiswa agar memiliki kompetensi kepribiadaian yang wajib dimiliki oleh guru. Berbagai penelitian telah dilakukan terkait dengan manfaat kegiatan KKN. Penelitian yang dilakukan oleh Yanti, C.W. B., Jaya, A.M., Fahrul. (2015)menunjukkan bahwa setelah mengikuti program KKN, para mahasiswa mendapatkan manfaat berupa pengembangan minat ilmu, kemampuan memahami persoalan di masyarakat sampai kemampuan mencari solusi pemecahan masalah. Selain itu, program ini juga meningkatkan empati dan kemampuan organisasi serta membantu mahasiswa dalam menyadari pentingnya time management. Pengalaman yang didapatkan melalui program KKN ini pada akhirnya dapat memberi sumbangsih pada pembentukan karakter dari mahasiswa peserta melalui proses pembelajaran dan interaksi sosial dengan masyarakat saat berada di lokasi. Hal ini akan membantu pembentukan kepribadian calon guru.

\section{Integrasi Nilai Keagamaan pada Perkuliahan}

Keberhasilan suatu proses habituasi berbanding lurus dengan lamanya waktu

penerapan. Semakin lama para calon guru dibiasakan dalam pembentukan kompetensi kepribadian, maka akan semakin dalam tertanam kepribadian yang baik, selanjutnya menjadi karakter di dalam diri calon guru tersebut. Nilai-nilai keagamaan dapat terapkan bersama dosen dan mahasiswa calon guru sepanjang pertemuan perkuliahan. Untuk mengawali hal ini yang diperlukan tidak lain adalah keteladanan dosen.

Beberapa contoh integrasi nilai keagamaan pada perkuliahan dalam rangka penanaman dan pembiasaan kompetensi kepribadian antara lain sebagai berikut:

1. Sebelum terlibat di dalam kegiatan perkuliahan, dosen berdoa dan mendoakan para mahasiswa calon guru supaya diberikan kemudahan dalam menerima ilmu, serta mendapatkan ilmu yang barokah dan bermanfaat.

2. Dosen datang tepat waktu dan siap sebelum jam perkuliahan dimulai.

3. Dosen menyampaikan salam untuk membuka perkuliahan dan memimpin berdoa atau mempersilahkan salah satu mahasiswa memimpin doa serta bersama-sama membaca hafalan sura-surah pendek dalam al Quran.

4. Dosen telah menyiapkan perangkat pembelajaran dengan skenario pembelajaran yang baik. Dalam penyusunan RPS dan penyajian materi perkuliahan dosen mengintegrasikan alQuran dan Hadis dalam mengkaji ilmu. 
5. Dosen memberikan teladan dalam berbusana, bertuturkata atau berkomunikasi, bersikap, dan berbuat selama proses perkuliahan.

6. Dosen menerapkan aturan-aturan ataupun tugas-tugas dengan penuh kedislipinan.

7. Dosen memberikan pembekalan yang kental dengan nuansa dan nilai keagamaan sebelum dilaksanakannya kegiatan PPL (Program Pengalaman Lapangan) di sekolah-sekolah mitra.

8. Dosen memberikan teladan pengambilan keputusan yang adil dan bijaksana sepanjang perkuliahan.

\section{SIMPULAN}

Kepribadian yang baik menjadi syarat yang harus dimiliki oleh para guru. Pembentukan kepribadian para calon guru perlu diprogramkan di institusi pencetak para calon guru khususnya menghadapi tantangan di era Disrupsi. Empat program menjadi sarana pembentuk kepribadian para calon guru di IAIN Tulungagung. Keempat program tersebut adalah Pendidikan Matrikulasi Agama, Kode Etik Mahasiswa, Kuliah Kerja Nyata, dan Integrasi Nilai keagamaan dalam Perkuliahan. Program-program tersebut bukan terpisah satu dengan lainnya, melainkan saling menguatkan untuk mewujudkan kompetensi kepribadian para calon guru. Kepribadian yang baik, andal, kuat, dan berakhlak karimah akan mampu menghadapi tantangan era disrupsi. Hasil keempat program yang telah dilaksanakan tersebut antara lain (1) mahasiswarata-rata hadir kuliah tepat waktu; (2) perkuliahan diawali dan diakhiri dengan berdoa (3) Mahasiswa membiasakan diri untuk menghafal surat-surat pendek di awal perkuliahan, (4) Mahasiswa terbebas dari faham radikalime, dan (5) Pengerjaan tugas-tugas tepat waktu. Untuk itu, kami berharap program ini dapat diterapkan oleh instusi lain pencetak para calon guru.

\section{DAFTAR PUSTAKA}

Ali, Maksum. (2016). Sosiologi Pendidikan. Malang: Madani

Aprilliyanti, Eka and Wahyu, Wahyu and Adawiah, Rabiatul (2013) Hubungan Kompetensi Kepribadian Guru PKN Dengan Sikap Demokratis Peserta Didik Di SMK Negeri 1 Banjarmasin. Jurnal Pendidikan Kewarganegaraan, 3 (5). pp. 354364. ISSN 230-2979 http://eprints.ulm.ac.id/95/

Departemen Pendidikan Nasional. 2006. Keputusan Direktur Jenderal Pendidikan Tinggi Departemen Pendidikan Nasional Republik Indonesia Nomor 43/DIKTI/Kep/2006 Tentang Rambu-Rambu-Rambu Pelaksanaan Kelompok Matakuliah pengembangan Kepribadian di Perguruan Tinggi

Departemen Pendidikan Nasional. 2007. Peraturan Menteri Pendidikan Nasional Republik Indonesia Nomor 16 Tahun 2007 tentang Standar Kualifikasi Akademik dan Kompetensi Guru

Indirawati, E. 2006. Hubungan Antara kematangan Beragama Dengan Kecenderungan Strategi Coping. Jurnal Psikologi Universitas Diponegoro Vol.3. No.2

Karwono dan Mularsih, Heni. (2017). Belajar dan Pembelajaran serta Pemanfaatan Sumber Belajar. Depok: Rajawali Pers.

Kheruniah, A.E. (2013). A Teacher Personality Competence Contribution To A Student Study Motivation And Discipline To Fiqh lesson. International Journal Of Scientific \& Technology Research, Volume 2, Issue 2. http://www.ijstr.org/final- 
print/feb2013/A-Teacher-Personality-Competence-Contribution-To-A-StudentStudy-Motivation-And-Discipline-To-Fiqh-Lesson.pdf.

Kristoto, P., Zakso, A., \& Rivale, W. 2015. Pengaruh Kompetensi Kepribadian Guru Terhadap Keberhasilan Siswa Dalam Belajar Sosiologi SMA Kemala Bhayangkari 1. Jurnal Pendidikan dan Pembelajaran Vol.4. No.12. http://jurnal.untan.ac.id/index.php/jpdpb/article/view/13001

Lembaga Penelitian Dan Pengabdian Kepada MasyarakatInstitut Agama Islam Negeri TulungagungTahun 2018

Muslimat, Ade. 2018. Generasi Era Disrupsi 9. diakses pada tanggal 1 Agustus 2018 https://www.kabar-banten.com/generasi-era-disrupsi/

Thayyarah, Nadiah. (2013). Buku Pintar Sains dalam Al Quran: Mengerti Mukjizat Ilmiah Firman Allah. Jakarta:Zaman.

Undang-Undang Nomor 14 Tahun 2005 tentang Guru dan Dosen 